\title{
Jan Krajczyński
}

\section{Swoboda wyboru formy zawarcia małżeństwa w Polsce}

Ius Matrimoniale 16 (22), 143-159

2011

Artykuł został opracowany do udostępnienia w internecie przez Muzeum Historii Polski w ramach prac podejmowanych na rzecz zapewnienia otwartego, powszechnego i trwałego dostępu do polskiego dorobku naukowego i kulturalnego. Artykuł jest umieszczony w kolekcji cyfrowej bazhum.muzhp.pl, gromadzącej zawartość polskich czasopism humanistycznych i społecznych.

Tekst jest udostępniony do wykorzystania w ramach dozwolonego użytku. 


\section{Ks. Jan Krajczyński}

\section{SWOBODA WYBORU FORMY ZAWARCIA MAŁŻEŃSTWA W POLSCE}

Jakkolwiek z chwilą przyjęcia chrześcijaństwa przez otoczenie Mieszka I od razu i w sposób kategoryczny nie uchylono w Polsce zwyczajowej, czysto świeckiej formy zawarcia małżeństwa ${ }^{1}$, wprawdzie nie bez trudności, niemniej stopniowo wprowadzano w życie przepisy Kościoła katolickiego ${ }^{2}$, który domagał się do ważności wspomnianej umowy publicznego wyrażenia zgody małżeńskiej wobec kapłana (coram Ecclesia, in faciae Ecclesiae) $)^{3}$. W praktyce jednak przez kolejne sześć stuleci, tj. aż do roku 1577, mianowicie - do przyjęcia przez Synod prowincjonalny piotrkowski ${ }^{4}$ uchwał Soboru Trydenckiego dotyczących formy zawarcia małżeństwa, strony mogły decydować o sposobie zawarcia małżeństwa. Co więcej, jeśli nawet wyrażały zgodę małżeńską w sposób potajemny, ich małżeństwo - wprawdzie niegodziwe i oficjalnie potępione przez Kościół - uchodziło za ważne ${ }^{5}$.

1 Szerzej na ten temat zob. W. Abraham, Zawarcie matżeństwa w pierwotnym prawie polskim, Lwów 1925.

2 Zob. W. Uruszczak, Funkcje publiczne Kościoła w Polsce w perspektywie historycznej, w: Funkcje publiczne związków wyznaniowych. Materiały III Ogólnopolskiego Sympozjum Prawa Wyznaniowego (Kazimierz Dolny, 16-18 maja 2006), pod red. A. Mezglewskiego, Lublin 2007, s. 31-32.

${ }^{3} \mathrm{Na}$ ten temat zob.: S. Biskupski, Prawo matżeńskie Kościoła rzymskokatolickiego, Warszawa 1956, t. 1, s. 320-328.

${ }^{4}$ Wcześniej, mianowicie w 1564 r., soborowy dekret Tametsi, który stanowił, że małżeństwo należy zawierać w obecności proboszcza lub kapłana mającego upoważnienie proboszcza albo ordynariusza i w obecności dwóch lub trzech świadków, przyjął Sejm Rzeczypospolitej Obojga Narodów na posiedzeniu w Parczewie.

5 ,Tametsi dubitandum non est, clandestina matrimonia, libero contrahentium consensu facta, rata et vetera esse matrimonia, quamdiu ecclesia ea irrita non fecit, et proinde iure damnandi sunt illi, ut eos sancta synodus anathemate damnat, qui ea vera negant [...] nihilominus sancta Dei ecclesia et ex iustissimis causis illa semper detestata est atque prohibuit". Canones et Decreta Concilii Tridentini. 
Chociaż przepisy dekretu Tametsi, określające formę prawną zawarcia małżeństwa, nie były dość precyzyjne, co w praktyce rodziło wiele kwestii natury pastoralnej i sądowniczej, nadto - w wielu Kościołach partykularnych usytuowanych na ziemiach polskich uchylono niektóre z nich ${ }^{6}$ z chwilą formalnego przyjęcia uchwał Soboru Trydenckiego kanoniczna forma zawarcia małżeństwa faktycznie nabrała w Polsce charakteru obligatoryjnego. Taki stan prawny przetrwał aż do 1 maja 1808 r., kiedy to w Księstwie Warszawskim przyjęto Kodeks cywilny Napoleona, z obowiązkową cywilną formą zawarcia małżeństwa. Jakkolwiek przepisy kodeksu o ślubach cywilnych utrzymano też w mocy w prawodawstwie Królestwa Polskiego $\left(27\right.$ XI 1815) ${ }^{7}$, rozwiązania takie, jako „niezgodne z duchem ustawodawstwa i tradycjami narodu polskiego"8, nie przyjęły się w praktyce'. W efekcie, w Dekrecie Cesarskim z 16 (28) marca 1836 r. ${ }^{10}$, określającym prawo dla Królestwa Polskiego, powrócono do znanej wcześniej kanonicznej formy zawarcia małżeństwa ${ }^{11}$. Naturalnie, wspomniane zasady prawne nie obowiązywały na terenach polskich, które wcielono do pozostałych dwóch zaborów. I tak na ziemiach, które w wyniku zaborów przyłączono do Prus, obowiązywały kolejno: Allgemeines Landrecht (1 III 1794) przewidujące zawarcie małżeństwa wobec duchownego, aczkolwiek zgodnie z jurysdykcją państwową; Ustawa o stanie cywilnym

${ }^{6}$ Zob.: S. Biskupski, Prawo matżeńskie Kościoła rzymskokatolickiego, s. 324.

7 Zob. W. Jemielity, Akta stanu cywilnego w Księstwie Warszawskim i Królestwie Polskim, „Prawo Kanoniczne” 38 (1995) nr 1-2, s. 163-164.

Kodeks napoleoński, w tym obowiązkowe małżeństwa cywilne, wprowadzono również w Wolnym Mieście Krakowie, czyli Rzeczypospolitej Krakowskiej, utworzonej na mocy aktu końcowego Kongresu Wiedeńskiego (9 czerwca 1815). Po upadku i wcieleniu do Austrii (16 listopada 1846) wprowadzono tutaj austriacki system prawny.

${ }^{8}$ T. Pawluk, Prawo kanoniczne wedtug Kodeksu Jana Pawła II, T. III, Prawo małżeńskie, Olsztyn 1984, s. 81.

9 Szerzej na ten temat zob.: H. Konic, Dzieje prawa matżeńskiego w Królestwie polskim, Kraków 1903; tenże, Prawo matżeńskie obowiazujace w byłym Królestwie Kongresowym, Warszawa 1924; J. Przygodzki, Stosunki między Kościołem katolickim a władzami Księstwa Warszawskiego w latach 1807-1812, w: Prawo wyznaniowe. Przeszłość i teraźniejszość. Materiały XI Konferencji historyków państwa i prawa, Kowary 6-8 września 2007 r., pod red. J. Koredczuka, Wrocław 2008, s. 161, 163-164.

10 Zob. Dziennik Praw Królestwa Polskiego, t. XVIII, s. 57-297.

11 Podobne zasady prawne, określone w Zwodzie Praw Cesarstwa Rosyjskiego z 1832 r., obowiązywały na dawnych Ziemiach Wschodnich, które znalazły się pod zaborem rosyjskim. Zob. T. X, cz. I. 
(6 II 1875) wprowadzająca obowiązkowe śluby cywilne zawierane przed urzędnikiem państwowym; Bürgerliches Gesetzbuch (1896), zgodnie z którym „małżeństwo zawiera się w ten sposób, że narzeczeni, osobiście i równocześnie obecni, oświadczają przed urzędnikiem stanu cywilnego, że chcą zawrzeć ze sobą małżeństwo" (§ 1317). W zaborze austriackim natomiast (z wykluczeniem Spisza i Orawy ${ }^{12}$ ) obowiązywała Allgemeines Bürgergesetzbuch (1 VI 1811) przyjmująca zasadę matrimonium civile subsidiarium, zgodnie z którą obowiązkową jest wyznaniowa forma zawarcia małżeństwa, a małżeństwo przed urzędnikiem państwowym mogą zawrzeć tylko ci, którzy nie mogą zawrzeć ślubu kościelnego, bądź też, jako bezwyznaniowcy, nie należą do żadnego związku wyznaniowego.

Wspomniane zróżnicowanie przepisów w zakresie sposobu zawarcia małżeństwa, które po zaborcach recypowała II Rzeczpospolita, próbowano usunać poprzez opracowanie jednolitych zasad prawnych, adekwatnych do religijnego i wyznaniowego kształtu społeczeństwa polskiego. Niestety, projekt prawa małżeńskiego Komisji Kodyfikacyjnej Rzeczypospolitej Polskiej z dnia 28 maja 1929 r., w myśl którego „po dopełnieniu czynności przedwstępnych przed właściwym urzędnikiem stanu cywilnego narzeczeni mogą zawrzeć ślub, składając publicznie przed urzędnikiem stanu cywilnego albo przed duszpasterzem zgodne oświadczenie w przytomności dwóch świadków, że zawierają dozgonny związek małżeński” (§ 24), natrafił na szeroki opór ze strony środowisk katolickich ${ }^{13}$ i w konsekwencji nigdy nie został przyjęty.

Stosownego ujednolicenia tego nad wyraz zróżnicowanego i niespójnego ustawodawstwa w przedmiocie procedury zawarcia małżeństwa, tym razem - bez żadnych konsultacji społecznych, dokonano z chwilą przejęcia władzy w Polsce przez reżim komunistyczny. Na mocy Dekretu Rady Ministrów z 25 września 1945 r. - Prawo mał-

12 Na Spiszu i Orawie początkowo obowiązywało wspomniane wyżej prawo austriackie z 1811 r., z wyznaniową formą zawarcia małżeństwa, z czasem uchylone ustawą z 1894 r., wprowadzającą na terenie całego Królestwa Węgier obowiązkowe małżeństwa cywilne. Zob. M. Allerhand, Prawo małżeńskie obowiqzujace na Spiszu i Orawie, Lwów 1926.

13 Zob. J. Krajczyński, Prawo polskie a prawo Kościoła katolickiego w Polsce $w$ zakresie procedury zawarcia matżeństwa w latach 1918-2009, w: Prawo państwowe a prawo wewnętrzne związków wyznaniowych. Pamiętnik VII Zjazdu Katedr i Wykładowców Prawa Wyznaniowego, Gniezno 11-12 IX 2010, Red. nauk.: K. Krasowski, M. Materniak-Pawłowska, M. Stanulewicz, Poznań 2010, s. 69-74. 
żeńskie ${ }^{14}$, jako obowiązkową przyjęto cywilną formę zawarcia małżeństwa. Opowiadając się za zasadą matrimonium civile obligatorium i odmawiając tym samym skutków cywilnoprawnych małżeństwom religijnym, wykluczono zarazem jakąkolwiek swobodę obywateli w zakresie wyboru formy zawarcia związku małżeńskiego. Wspomniane restrykcyjne zasady prawne w przedmiocie formy zawarcia małżeństwa potwierdzano w kolejnych kodyfikacjach polskiego prawa rodzinnego ${ }^{15}$. Uchyliła je dopiero Ustawa z 24 lipca 1998 r. o zmianie ustaw - Kodeks rodzinny i opiekuńczy, Kodeks postępowania cywilnego, Prawo o aktach stanu cywilnego, ustawy o stosunku Państwa do Kościoła Katolickiego w Rzeczypospolitej Polskiej oraz niektórych innych ustaw ${ }^{16}$.

Nowelizacja przepisów prawa polskiego w zakresie sposobu zawarcia małżeństwa, dokonana na mocy wspomnianej ustawy, stanowiła konsekwencję ratyfikacji Konkordatu między Stolicą Apostolską i Rzeczapospolitą Polską ${ }^{17}$ i wykonanie art. 10 ust. 6 tejże umowy. W nowej regulacji przyjęto zasadę swobody stron w zakresie wyboru formy zawarcia małżeństwa. W praktyce od dnia 15 listopada 1998 r., tj. od wejścia w życie stosownych przepisów wykonawczych, precyzujących tryb postępowania przy zawieraniu małżeństwa w formie wyznaniowej, kontrahenci mogą wybierać pomiędzy cywilną a wyznaniową formą zawarcia związku małżeńskiego.

Wspomnianą zasadę swobody nupturientów co do wyboru formy zawarcia małżeństwa zdaje się podważać regulacja przyjęta przez par-

14 Zob. Dz. U z 1945 r. Nr 48, poz. 270.

15 Zob. Ustawa z 27 czerwca 1950 r. - Kodeks rodzinny i opiekuńczy, Dz. U. z 1950 r. Nr 34, poz. 308; Dekret Rady Ministrów z 8 czerwca 1955 r. - Prawo o aktach stanu cywilnego, Dz. U. z 1955 r. Nr 25, poz. 151; Ustawa z 2 grudnia 1958 r. o zmianie przepisów prawa o aktach stanu cywilnego, Dz. U. z 1958 r. Nr 72, poz. 358; Ustawa z 25 lutego 1964 r. - Kodeks rodzinny i opiekuńczy, Dz. U. z 1964 r. Nr 9, poz. 59; Ustawa z 19 grudnia 1975 r. o zmianie ustawy - Kodeks rodzinny i opiekuńczy, Dz. U. z 1975 r. Nr 45, poz. 234; Ustawa z 29 września 1986 r. - Prawo o aktach stanu cywilnego, Dz. U. z 1986 r. Nr 36, poz. 180 z późn. zm.

Szerzej na ten temat zob.: J. Skąpski, Kodeks cywilny z 1964 r. Blaski i cienie kodyfikacji oraz jej perspektywy, „Kwartalnik Prawa Prywatnego” 1992, z. 1-4, s. 57-89; Polskie prawo wyznaniowe, pod red. nauk. J. Krukowskiego, Warszawa 2000, s. 252253; A. Mezglewski, A. Tunia, Wyznaniowa forma zawarcia matżénstwa cywilnego, Warszawa 2007, s.7-11.

16 Zob. Dz. U. z 1998 r. Nr 117, poz. 757.

17 Zob. Ustawa z 8 stycznia 1998 r. o ratyfikacji Konkordatu między Stolicą Apostolską i Rzecząpospolitą Polską, Dz. U. z 1998 r. Nr 12, poz. 42. 
tykularnego ustawodawcę kościelnego ${ }^{18}$, mianowicie zapis przewidziany w art. 3 Instrukcji Konferencji Episkopatu Polski dla duszpasterzy z dnia 22 października 1998 r. dotyczącej małżeństwa konkordatowego, gdzie postanowiono, że ,wierni Kościoła katolickiego w Polsce zawierający małżeństwo kanoniczne mają obowiązek uzyskania dla niego skutków cywilnych, zapewnionych w Konkordacie". Niniejsza publikacja stanowi próbę odniesienia się do tego rzekomego ograniczenia podmiotowych praw części obywateli Polski, którzy w myśl kan. 205 KPK pozostają w pełnej wspólnocie Kościoła katolickiego a tym samym są zobowiązani do zachowania przepisów prawa kanonicznego w zakresie formy zawarcia małżeństwa.

\section{Gwarancje dotyczące formy zawarcia małżeństwa zawarte w Konkordacie}

W art. 10 ust. 1 Konkordatu z 28 lipca 1993 r. przyjęto następującą zasadę w przedmiocie zawarcia małżeństwa kanonicznego: „Od chwili zawarcia małżeństwo kanoniczne wywiera takie skutki, jakie pociaga za sobą zawarcie małżeństwa zgodnie z prawem polskim, jeżeli między nupturientami nie istnieją przeszkody wynikające z prawa polskiego, złożą oni przy zawieraniu małżeństwa zgodne oświadczenie woli dotyczące wywarcia takich skutków i zawarcie małżeństwa zostało wpisane w aktach stanu cywilnego na wniosek przekazany urzędowi stanu cywilnego w terminie pięciu dni od zawarcia małżeństwa; termin ten ulega przedłużeniu, jeżeli nie został dotrzymany z powodu siły wyższej, do czasu ustania tej przyczyny".

Jakkolwiek wspomniany artykuł Konkordatu uzyskał walor normy prawa krajowego z chwilą ratyfikacji Konkordatu i ogłoszenia go w „Dzienniku Ustaw”, ponieważ nie zawierał norm kompletnych, które nadają się do bezpośredniego stosowania, ale klauzule odsyłające do ustaw zwykłych ${ }^{19}$, układające się strony dodały, iż celem wprowadze-

18 Taką właśnie kwestię przedłożył w dniu 12 września 2010 r., w ramach dyskusji podczas VII Zjazdu Katedr i Wykładowców Prawa Wyznaniowego", Prof. K. Krasowski, Prorektor UAM w Poznaniu.

19 Szerzej na ten temat zob.: J. Krukowski, Przesłanki stosowania Konkordatu z 1993 r. w polskim porzqdku prawnym, w: Finis legis Christus. Księga pamiątkowa dedykowana Księdzu Profesorowi Wojciechowi Góralskiemu z okazji siedemdziesiątej rocznicy urodzin, red. J. Wroceński, J. Krajczyński, T. 2, Warszawa 2009, s. $1092-$ 1095 . 
nia w życie niniejszego artykułu dokonane zostaną konieczne zmiany w prawie polskim (zob. art. 10 ust. 6).

Postanowienie art. 10 ust. 1 Konkordatu, oznaczające wprowadzenie w polskim porządku prawnym nowej formy zawarcia małżeństwa, niewatpliwie poszerza, $i$ to $\mathrm{w}$ istotnej mierze, zakres podmiotowej wolności obywateli Rzeczypospolitej Polskiej. Legalizując alternatywną i równorzędna, wyznaniową formę zawarcia małżeństwa, gwarantuje ono nupturientom, którzy chcą zawrzeć małżeństwo według zasad prawa kanonicznego, wolność w zakresie sposobu zawarcia małżeństwa ze skutkami cywilnoprawnymi. Pozwala im mianowicie dokonać w pełni swobodnego wyboru pomiędzy znaną wcześniej, cywilną formą zawarcia małżeństwa, a „odpowiadającą potrzebom i oczekiwaniom znacznej części społeczeństwa"20, wyznaniową formą zawarcia takiego związku.

Wprawdzie regulacja taka nie ma charakteru powszechnego, odnosi się bowiem tylko i wyłącznie do zawarcia małżeństwa kanonicznego, ponadto - posiada jedynie charakter ogólny, gdzie przepisy Konkordatu nie nadają się do bezpośredniego stosowania, z pewnością stanowi duży krok w kierunku przyjęcia przez ustawodawcę polskiego pełnej swobody w zakresie wyboru przez kontrahentów sposobu ukonstytuowania stosunku małżeństwa w rozumieniu prawa polskiego.

Przyjęcie zasady, w myśl której prawo polskie tak samo traktuje małżeństwa zawierane przed urzędnikiem państwowym i przed duchownym Kościoła katolickiego (matrimonium civile facultativum), przy jednoczesnym uchyleniu zasady, zgodnie z którą małżeństwo wyznaniowe nie jest uznawane za zdarzenie prawne, oznacza odstapienie prawodawcy od narzucanego przez obowiązujący wcześniej reżim komunistyczny PRL jedynego legalnego sposobu zawarcia małżeństwa ${ }^{21}$. Rozwiązanie takie, jakkolwiek nowatorskie w systemie prawa polskiego, nie oznacza bynajmniej, iż Rzeczpospolita Polska zrezygnowała - choćby w najmniejszym stopniu - z unormowania tak doniosłej dziedziny życia społecznego, jaką jest zawieranie związków małżeńskich; państwo polskie ograniczając jedynie własną aktywność w tej dzie-

${ }^{20}$ Zob. W. Góralski, Zawarcie matżeństwa konkordatowego w Polsce, Warszawa 1998, s. 11.

${ }^{21}$ Por. J. Wroceński, Le conseguenze canoniche e civili del matrimonio concordatario celebrato in Polonia, w: „Iustitia et iudicium”. Studi di diritto matrimoniale e processuale canonico in onore di Antoni Stankiewicz, a cura di J. Kowal e J. Llobell, „Studi Giuridici” LXXXIX, Libreria Editrice Vaticana 2010, vol. II, s. 1056. 
dzinie $^{22}$, uznało za słuszne zagwarantować obywatelom prawo wyboru formy zawarcia małżeństwa.

Bezsprzecznie, jak zauważa W. Góralski, wprowadzenie do prawa polskiego instytucji małżeństwa konkordatowego, a tym samym zagwarantowanie obywatelom prawa wyboru formy zawarcia małżeństwa, należy uznać za wyraz urzeczywistniania konstytucyjnej zasady wolności sumienia i religii (art. 53) ${ }^{23}$, w tym także poszanowania pluralizmu przekonań o statusie ideologicznym, religijnym i prawnym osoby ludzkiej ${ }^{24}$. Taka różnorodność form zawarcia małżeństwa, dopuszczana przez prawo konkordatowe od lat osiemdziesiątych XIX wieku, z zasady służy osiagnięciu tych samych celów ${ }^{25}$; mianowicie: powstaniu stosunku prawnego małżeństwa $\mathrm{w}$ rozumieniu prawa polskiego. Inaczej, w jednym i drugim przypadku - czy to składając oświadczenie woli o zawarciu małżeństwa przed kierownikiem urzędu stanu cywilnego, czy też zawierając małżeństwo kanoniczne, które wywiera takie skutki, jakie pociąga za sobą zawarcie małżeństwa zgodnie z prawem polskim - strony wchodzą w relację małżeństwa określoną w polskim systemie prawnym.

Wspomniane rozwiązania w przedmiocie wyboru formy zawarcia małżeństwa, przyjęte w umowie konkordatowej z 1993 r., zdecydowanie należy określić jako wysoce praktyczne, dokonane w duchu realizmu prawnego, odpowiadające na bardzo konkretne i żywotne oczekiwania znacznej części obywateli RP. Normy przyjęte w art. 10 ust. 1 Konkordatu, z jednej strony - wolne od złożonych uwarunkowań historycznych, z drugiej zaś - w pełni respektujące autonomię

${ }^{22}$ Zob. W. Góralski, Funkcje publiczne duchownego przy zawieraniu matżeństwa konkordatowego, w: Funkcje publiczne związków wyznaniowych. Materiały III Ogólnopolskiego Sympozjum Prawa Wyznaniowego (Kazimierz Dolny, 16-18 maja 2006), pod red. A. Mezglewskiego, Lublin 2007, s. 348-349.

${ }^{23}$ Tamże, s. 349. Zob. także P. Majer, Uwagi odnośnie do małżeństwa konkordatowego - art. 10 Konkordatu z 1993 roku a ustawodawstwo państwowe, „Ius Matrimoniale" 6 (12 ) 2001, s. 157-158.

${ }^{24}$ Por. J. Hołda, Z. Hołda, D. Ostrowska, J.A. Rybczyńska, Prawa człowieka. Zarys wykładu, Kraków 2004, s. 150.

A propos przekonań dotyczących statusu osoby, należy pamiętać, że w przypadku zawierania związku małżeńskiego przez członków Kościoła katolickiego tylko te małżeństwa są ważne, które zostają zawarte wobec asystującego miejscowego ordynariusza albo proboszcza, albo wobec kapłana lub diakona delegowanego przez jednego z nich, oraz wobec dwóch świadków. Por. kan. 1108 § 1 KPK.

${ }^{25}$ Zob. W. Adamczewski, Przepisy matżeńskie konkordatu polskiego na tle innych umów konkordatowych, „Ius Matrimoniale” 6 (12) 2001 s. 132-136. 
i niezależność stron umowy, faktycznie ułatwiają życie osób, które posiadają wolę zawarcia małżeństwa ${ }^{26}$. Przyjęcie tych norm nabiera jeszcze większego znaczenia społecznego dzisiaj, kiedy tak wielu młodych obywateli Polski w ogóle nie jest zainteresowanych zawarciem formalnego związku małżeńskiego.

W praktyce, zmiana przepisów dotyczących sposobu zawierania małżeństwa, dokonana $\mathrm{w}$ następstwie transformacji ustrojowych w III Rzeczypospolitej, sprawiła, iż członkowie Kościoła katolickiego w Polsce, którzy wcześniej byli zobligowani zawierać dwa małżeństwa, tj. najpierw obowiązkowe małżeństwo cywilne, według formy określonej przez prawo polskie, w celu uzyskania skutków cywilnych, a następnie - zgodnie ze swoimi przekonaniami religijnymi - małżeństwo kościelne, według formy określonej przez prawo kanoniczne ${ }^{27}$, mogą teraz zawrzeć jednocześnie małżeństwo o podwójnych skutkach prawnych (kanonicznych i cywilnych) ${ }^{28}$ bądź też - jak wcześniej - po dwakroć publicznie wyrażać wolę zawarcia małżeństwa (raz w formie kanonicznej, raz - cywilnej). Wspomniana zasada autonomiczności woli nupturientów co do wywarcia skutków cywilnych małżeństwa, zapisana w art. 10 ust. 2 Konkordatu, stanowi nie tylko istotne novum i element charakterystyczny dla tej umowy ${ }^{29}$. Regulacja ta - formalnie stwarzając i zabezpieczając prawo kontrahentów do wyboru formy zawarcia małżeństwa oraz powierzając uprawnionym duchownym zadania i funkcje z zakresu rejestracji stanu cywilnego ${ }^{30}$, tak by osoby, które posiadają wolę zawarcia małżeństwa kanonicznego ze skutkami cywilnymi, mogły faktycznie skorzystać z prawa wyboru sposobu powstania stosunku małżeństwa - niewątpliwie szanuje ,całkowitą wolność nupturientów co do tego, jakie zawrą małżeństwo i na jakim

26 Zob. Tamże, s. 143.

27 Polskie prawo wyznaniowe, pod red. nauk. J. Krukowskiego, Warszawa 2000, s. 253.

${ }_{28}$ Zob. A. Mezglewski, H. Misztal, P. Stanisz, Prawo wyznaniowe, Warszawa 2006, s. 143.

${ }_{29}$ Zob. W. Adamczewski, Przepisy matżeńskie konkordatu polskiego na tle innych umów konkordatowych, „Ius Matrimoniale” 6 (12) 2001 s. 138.

${ }^{30}$ Szerzej na temat tych zadań i funkcji zob. W. Góralski, Funkcje publiczne duchownego przy zawieraniu matżeństwa konkordatowego, w: Funkcje publiczne związków wyznaniowych. Materiały III Ogólnopolskiego Sympozjum Prawa Wyznaniowego (Kazimierz Dolny, 16-18 maja 2006), pod red. A. Mezglewskiego, Lublin 2007, s. 341-350. 
forum ma ono wywierać skutki”31. Jak najbardziej, wszystko to dokonuje się przy zachowaniu wyłącznej kompetencji państwa w zakresie określenia skutków cywilnych małżeństwa kanonicznego, okoliczności wyłączających zawarcie małżeństwa i warunków rejestracji stanu cywilnego.

\section{Normy w obowiązującym prawodawstwie polskim}

Ustawodawca polski przy pomocy dwóch aktów normatywnych, mianowicie: Ustawy z 26 czerwca 1997 r. o zmianie ustawy o gwarancjach wolności sumienia i wyznania i niektórych innych ustaw ${ }^{32}$ oraz Ustawy z 24 lipca 1998 r. o zmianie ustaw - Kodeks rodzinny i opiekuńczy, Kodeks postępowania cywilnego, Prawo o aktach stanu cywilnego, ustawy o stosunku Państwa do Kościoła Katolickiego w Rzeczypospolitej Polskiej oraz niektórych innych ustaw ${ }^{33}$, określił w sposób szczegółowy zasady dotyczące wymienionych wyżej równorzędnych form zawarcia małżeństwa. Istotę wspomnianej nowelizacji przepisów prawa polskiego w zakresie sposobu zawarcia małżeństwa można sprowadzić do następującego zapisu: małżeństwo zawarte według prawa wewnętrznego danego kościoła albo innego związku wyznaniowego wywiera takie skutki jak małżeństwo zawarte przed kierownikiem urzędu stanu cywilnego, jeśli spełnione zostały wymagania określone w Kodeksie rodzinnym i opiekuńczym (dalej: KRO).

Rozszerzenie art. 1 KRO o treść paragrafu 2 i 3 oznacza zagwarantowanie znacznej części obywateli RP faktycznej wolności w zakresie wyboru sposobu zawarcia małżeństwa w rozumieniu prawa polskie$\mathrm{go}^{34}$. Innymi słowy, osoby te - czy to kierując się racjami natury religijnej, czy też innymi - mogą dokonać w pełni swobodnego wyboru pomiędzy zawarciem małżeństwa w trybie art. $1 \S 1 \mathrm{KRO}$, tj. przed kierownikiem urzędu stanu cywilnego, a zawarciem zgodnie z przepisami art. $1 \S 2-3 \mathrm{KRO}$, kiedy to zawierając związek małżeński podlegający prawu wewnętrznemu kościoła albo innego związku wyznaniowego

31 Deklaracja Rządu RP w sprawie Konkordatu z 15 IV 1997 r., w: W. Góralski, Konkordat polski 1993 od podpisania do ratyfikacji, Warszawa 1998, s. 104.

32 Zob. Dz. U. z 1997 r. Nr 59, poz. 375.

33 Zob. Dz. U. z 1998 r. Nr 117, poz. 757.

${ }^{34}$ Zob. W. Góralski, Forma zawarcia matżeństwa wedtug art. 1, $22 \mathrm{KRO}$, „Prawo Kanoniczne" 46 (2003) nr 1-2, s. 109. 
oświadczą w obecności uprawnionego duchownego wolę jednoczesnego zawarcia małżeństwa podlegającego prawu polskiemu.

Jakkolwiek ustawodawca, kierując się konstytucyjnymi zasadami: równouprawnienia wszystkich ludzi bez względu na ich wyznanie (art. 32) oraz równości kościołów i innych związków wyznaniowych (art. 25 ust. 1), rozszerzył uprawnienie do rejestracji małżeństw kanonicznych, jakim na mocy Konkordatu z 1993 r. cieszył się Kościół katolicki, na inne kościoły i związki wyznaniowe, nie nadał on wspomnianemu uprawnieniu charakteru powszechnego. Postanawiając, że tego rodzaju procedurę mogą stosować tylko te kościoły i związki wyznaniowe, którym zagwarantowano takie uprawnienie w ratyfikowanej umowie międzynarodowej lub w ustawie regulującej stosunki między państwem a kościołem albo innym związkiem wyznaniowym ${ }^{35}$, wykluczył on - przynajmniej czasowo - możliwość nadania tego uprawnienia wszystkim kościołom i związkom wyznaniowym, które prowadzą w Polsce działalność religijna, czy to na mocy stosownych ustaw, czy też posiadają status uregulowany $\mathrm{w}$ formie rejestracji, na warunkach określonych w Ustawie z dnia 17 maja 1989 r. o gwarancjach wolności sumienia i wyznania. Opowiedzenie się za zasadą indywidualnego nadania wspomnianego uprawnienia kościołom i związkom wyznaniowym, jakkolwiek rodzi kontrowersje i pytania o realizację zasady równouprawnienia obywateli, jest jak najbardziej zasadne. Racje takiego rozstrzygnięcia stanowią: troska o samo małżeństwo jako instytucję o istotnym znaczeniu społecznym, mianowicie skuteczna kontrola państwa wymienionych zdarzeń prawnych, oraz zabezpieczenie podstawowych interesów majątkowych i niemajątkowych małżonków $\mathrm{i}$ ich potomstwa ${ }^{36}$.

Wprowadzenie do polskiego porządku prawnego instytucji małżeństwa wyznaniowego ze skutkami cywilnymi oraz rozszerzenie zasady uznania skutków cywilnych małżeństwa kanonicznego na małżeństwa zawierane w innych kościołach albo związkach wyznaniowych, postulowane zresztą przez wielu uczonych ${ }^{37}$, niewątpliwie służy budowaniu

${ }^{35}$ Zob. Art. $1 \S 3$ KRO.

${ }^{36}$ Por. A. Mezglewski, H. Misztal, P. Stanisz, Prawo wyznaniowe, Warszawa 2006, s. 144.

${ }^{37}$ Zob.: R. Sobański, Uwagi o zmianach w prawie polskim postulowanych art. 10 Konkordatu z 28 lipca 1993 roku, w: B. Czech (red.), Czy potrzebna jest w Polsce zmiana prawa rodzinnego i opiekuńczego, Katowice 1997, s. 285-286; A. Mączyński, Wplyw konkordatu na polskie prawo matzeńskie, w: Studia z prawa prywatnego. 
społeczeństwa obywatelskiego, opartego na poszanowaniu podstawowych wartości ludzkich, jakimi są godność ludzka oraz poszanowanie praw człowieka, zwłaszcza prawa do wolności.

Ustawowe uregulowanie nowej formy zawarcia małżeństwa formalnie czyni zadość temu, co zapisano w art. 10 ust. 6 Konkordatu. Niemniej należy wyraźnie zaznaczyć, iż wspomniane ustawowe rozwiązania $\mathrm{w}$ przedmiocie formy zawarcia małżeństwa nie oddają dokładnie tego, co w tym względzie uzgodniły Stolica Apostolska i Rzeczpospolita Polska. Sformułowanie konkordatowe: „od chwili zawarcia małżeństwo kanoniczne wywiera takie skutki, jakie pociaga za sobą zawarcie małżeństwa zgodnie z prawem nie polskim" (art. 10 ust. 1) nie jest tożsame z przewidzianym przez KRO: oświadczeniem przez mężczyznę i kobietę, którzy zawierają małżeństwo kanoniczne, w obecności duchownego ,woli jednoczesnego zawarcia małżeństwa podlegającego prawu polskiemu" (zob. art. $1 \S 2 \mathrm{KRO})^{38}$. Inaczej, w miejsce konkordatowej zasady matrimonium civile facultativum ustawodawca polski wprowadził zasadę matrimonium civile obligatorium, $\mathrm{z}$ dwiema równorzędnymi formami zawarcia małżeństwa, cywilną i wyznaniową ${ }^{39}$.

Nowelizacja prawa w przedmiocie sposobu zawarcia małżeństwa, dokonana w wyżej wymienionych ustawach - poszerzając zakres osób, które mogą skorzystać z prawa wyboru formy zawarcia małżeństwa, pomiędzy cywilną i wyznaniową - w istotnej mierze korzystnie wpływa na sytuację prawną innych kościołów i związków wyznaniowych ${ }^{40}$. Rozszerzając gwarancje wolnościowe, zapisane w Konkordacie, a dotyczące uznania skutków cywilnych małżeństw zawartych w formie wyznaniowej, na inne kościoły i związki wyznaniowe, ustawodawca

Księga pamiątkowa ku czci Profesor Biruty Lewaszkiewicz-Petrykowskiej, Łódź 1997, s. 130.

38 Zob. W. Adamczewski, Przepisy matżeńskie konkordatu polskiego na tle innych umów konkordatowych, „Ius Matrimoniale” 6 (12) 2001, s. 129; A. Mezglewski, A. Tunia, Wyznaniowa forma zawarcia matzeństwa cywilnego, Warszawa 2007, s. 21; P. Majer, Zawarcie małżeństwa kanonicznego bez skutków cywilnych, Kraków 2009, s. 468 .

39 Zob. P. Majer, Zawarcie małżeństwa kanonicznego bez skutków cywilnych, Kraków 2009, s. 468.

${ }^{40}$ Por.: W. Wysoczański, Wpływ Konkordatu z 1993 r. na sytuację prawna kościotów $i$ innych zwiqzków wyznaniowych mniejszościowych, w: Konkordat polski w 10 lat po ratyfikacji, Warszawa 2008, s. 84; J. Krukowski, Przesłanki stosowania Konkordatu z 1993 r. w polskim porzadku prawnym, s. 1096-1097. 
usuwa wszelkie pozory dyskryminacji czy deprecjacji tych wspólnot religijnych. Wystarczy, że kościoły te albo związki wyznaniowe zwrócą się z wnioskiem o dokonanie stosownych poprawek w aktach regulujących ich status prawny, a mogą otrzymać gwarancję stosowania wyznaniowej formy zawarcia małżeństwa ${ }^{41}$.

Bez watpienia ustalenie nowego, alternatywnego trybu zawierania małżeństw cywilnych oraz określenie procedury umożliwiającej zawarcie małżeństwa o podwójnych skutkach, wyznaniowych i cywilnych, należy uznać za przejaw normalizacji i demokratyzacji życia społecznego w Polsce ${ }^{42}$. Same zaś pozytywne gwarancje prawa do wyboru formy zawarcia małżeństwa, wprowadzone przez znowelizowany KRO i nowelizację dziesięciu innych ustaw określających pozycję prawną poszczególnych kościołów albo związków wyznaniowych ${ }^{43}$, wyraźnie wskazuja, iż wolą prawodawcy polskiego jest zagwarantowanie równych praw wszystkim nupturientom, bez względu

${ }^{41}$ Wniosku takiego nie złożył np. Kościół Katolicki Mariawitów w Rzeczypospolitej Polskiej. Jakkolwiek jego sytuacja prawna została uregulowana na mocy stosownej ustawy, nie ma w tym akcie normatywnym żadnej wzmianki nt. wspomnianej gwarancji. Zob. Ustawa z dnia 20 lutego 1997 r. o stosunku Państwa do Kościoła Katolickiego Mariawitów w Rzeczypospolitej Polskiej, Dz. U. z 1997, Nr 41, poz. 252 ze zm.

42 Por. A. Mezglewski, H. Misztal, P. Stanisz, Prawo wyznaniowe, Warszawa 2006, s. 143.

${ }^{43}$ Zob. Ustawa z dnia 4 lipca 1991 r. o stosunku Państwa do Polskiego Autokefalicznego Kościoła Prawosławnego w Rzeczypospolitej Polskiej, Dz. U. z 1991, Nr 66, poz. 287 ze zm.; Ustawa z dnia 13 maja 1994 r. o stosunku Państwa do Kościoła Ewangelicko-Augsburskiego w Rzeczypospolitej Polskiej, Dz. U. z 1994, Nr 73, poz. 323 ze zm.; Ustawa z dnia 13 maja 1994 r. o stosunku Państwa do Kościoła Ewangelicko-Reformowanego w Rzeczypospolitej Polskiej, Dz. U. z 1994, Nr 73, poz. 324 ze zm.; Ustawa z dnia 30 czerwca 1995 r. o stosunku Państwa do Kościoła Ewangelicko-Metodystycznego w Rzeczypospolitej Polskiej, Dz. U. z 1995, Nr 97, poz. 479 ze zm.; Ustawa z dnia 30 czerwca 1995 r. o stosunku Państwa do Kościoła Chrześcijan Baptystów w Rzeczypospolitej Polskiej, Dz. U. z 1995, Nr 97, poz. 480 ze zm.; Ustawa z dnia 30 czerwca 1995 r. o stosunku Państwa do Kościoła Adwentystów Dnia Siódmego w Rzeczypospolitej Polskiej, Dz. U. z 1995, Nr 97, poz. 481 ze zm.; Ustawa z dnia 30 czerwca 1995 r. o stosunku Państwa do Kościoła Polskokatolickiego w Rzeczypospolitej Polskiej, Dz. U. z 1995, Nr 97, poz. 482 ze zm.; Ustawa z dnia 20 lutego 1997 r. o stosunku Państwa do gmin wyznaniowych żydowskich w Rzeczypospolitej Polskiej, Dz. U. z 1997, Nr 41, poz. 251 ze zm.; Ustawa z dnia 20 lutego 1997 r. o stosunku Państwa do Kościoła Starokatolickiego Mariawitów w Rzeczypospolitej Polskiej, Dz. U. z 1997, Nr 41, poz. 253 ze zm.; Ustawa z dnia 20 lutego 1997 r. o stosunku Państwa do Kościoła Zielonoświątkowego w Rzeczypospolitej Polskiej, Dz. U. z 1997, Nr 41, poz. 254 ze zm. 
na ich przekonania religijne i przynależność kościelną. Rozwiązania przyjęte we wspomnianych ustawach, jakkolwiek dalekie od ideału ${ }^{44}$, poszerzają sferę wolności obywatelskich w Polsce, czyniąc zarazem zadość zasadom określonym w ustawie zasadniczej oraz w aktach prawa międzynarodowego, jakie przyjęła, ratyfikowała i potwierdziła Rzeczypospolita Polska ${ }^{45}$.

\section{Wymóg instrukcji KEP z 1998 r. o obowiązku zawarcia małżeństwa ze skutkami cywilnymi}

Jak już zaznaczono, znowelizowany KRO zagwarantował osobom, które pragną zawrzeć małżeństwo religijne zgodnie z prawem własnego kościoła albo związku wyznaniowego i małżeństwo cywilne podlegające prawu polskiemu, możliwość dokonania tego jednocześnie, tj. w trybie art. $1 \S 2$ i $3 \mathrm{KRO}$, lub oddzielnie, mianowicie: przed kierownikiem urzędu stanu cywilnego według zasad określonych w art. $1 \S 1$ KRO oraz stosownie do przepisów prawa swego kościoła albo związku wyznaniowego. W przypadku członków Kościoła katolickiego w Polsce, zakres wspomnianej swobody co do wyboru formy zawarcia małżeństwa przybiera nieco inny kształt. Otóż, zgodnie z uchwałą Konferencji Episkopatu Polski, która uzyskała recognitio Stolicy

44 Jako niekoniecznie wzorcowe dyspozycje, które przyjęto w znowelizowanych regulacjach ustawowych dotyczących formy zawarcia małżeństwa, można wskazać m.in. te, które określają osoby uprawnione do przyjęcia oświadczeń nupturientów o zawarciu małżeństwa w trybie art. 1 § 2 i 3 KRO czy precyzują czas i sposób złożenia oświadczenia woli jednoczesnego zawarcia małżeństwa podlegającego prawu polskiemu przez osoby, które zawierają związek małżeński podlegający prawu wewnętrznemu kościoła albo innego związku wyznaniowego.

${ }^{45}$ Mowa tu przede wszystkim o następujących aktach prawnych: Konstytucja Rzeczypospolitej Polskiej z dnia 2 kwietnia 1997 r. (art. 25 ust. 1, art. 32 ust. 1, art. 53 ust. 2), Dz. U. z 1997 r. Nr 78, poz. 483 ze zm.; Międzynarodowy Pakt Praw Obywatelskich i Politycznych otwarty do podpisu w Nowym Jorku dnia 19 grudnia 1966 r. (art. 2 ust. 1, art. 3, art. 23 ust. 4), Dz. U. z 1977 r. Nr 38, poz. 167; Międzynarodowy Pakt Praw Gospodarczych, Społecznych i Kulturalnych otwarty do podpisu w Nowym Jorku dnia 19 grudnia 1966 r. (art. 3), Dz. U. z 1977 r. Nr 38, poz. 169; Deklaracja w sprawie Eliminacji Wszelkich Form Nietolerancji i Dyskryminacji opartych na Religii lub Przekonaniach uchwalona przez Zgromadzenie Ogólne Narodów Zjednoczonych w dniu 25 listopada 1981 r. (art. 2 ust. 1), Konwencja o Ochronie Praw Człowieka i Podstawowych Wolności sporządzona w Rzymie dnia 4 listopada 1950 r., zmieniona następnie Protokołami nr 3, 5 i 8 oraz uzupełniona Protokołem nr 2 (art. 14), Dz. U. z 1993 r. Nr 61, poz. 284. 
Apostolskiej, „Zasadniczo wszystkie małżeństwa kościelne winny mieć gwarantowane skutki cywilne, przewidziane prawem polskim”46. Innymi słowy, ustawodawca kościelny postanawiając, że „,wierni Kościoła katolickiego w Polsce zawierający małżeństwo kanoniczne mają obowiązek uzyskania dla niego skutków cywilnych, zapewnionych w Konkordacie (art. 10)" ${ }^{\prime 47}$, domaga się, aby osoby te, ilekroć chcą wstapić w związek małżeński, uczyniły to albo poprzez zawarcie małżeństwa $\mathrm{w}$ formie wyznaniowej, zgodnie $\mathrm{z}$ procedurą określoną w części III lub IV Instrukcji (art. 11-26), albo poprzez uprzednie zawarcie małżeństwa cywilnego przed kierownikiem urzędu stanu cywilnego a następnie małżeństwa kanonicznego, zgodnie z wymogami określonymi w Instrukcji Konferencji Episkopatu Polski o przygotowaniu do zawarcia małżeństwa w Kościele katolickim z 13 grudnia $1989 \mathrm{roku}^{48}$.

W konsekwencji, w Instrukcji Konferencji Episkopatu Polski dla duszpasterzy z dnia 22 października 1998 r. dotyczącej małżeństwa konkordatowego przyjęto zasadę, że bez zgody ordynariusza miejsca nie wolno asystować przy zaślubinach osób, które nie chcą, by ich małżeństwo wywierało skutki w prawie polskim ${ }^{49}$. Wspomniany zakaz, który bezpośrednio dotyczy duszpasterzy posiadających upoważnienie do asystowania przy zawarciu małżeństwa, może uchylić ordynariusz miejsca, poprzez udzielenie zezwolenia na zawarcie małżeństwa bez skutków cywilnych, ale „tylko w wyjątkowych przypadkach z ważnych powodów pastoralnych" 50 .

Taki kształt regulacji, jakkolwiek pośrednio ogranicza swobodę nupturientów w przedmiocie zawarcia małżeństwa ${ }^{51}$, faktycznie stanowi jeden z instrumentów ochrony nadrzędnych i podstawowych rzeczywistości w życiu Kościoła i społeczności państwowej, jakimi są

46 Instrukcja Konferencji Episkopatu Polski dla duszpasterzy z dnia 22 października 1998 r. dotycząca małżeństwa konkordatowego, art. 5, „Biuletyn Katolickiej Agencji Informacyjnej”, 17 listopada 1998, s. 15.

47 Tamże, art. 3 .

48 Zob. „Akta Konferencji Episkopatu Polski” 1 (1998) s. 83-108.

49 Zob. Instrukcja Konferencji Episkopatu Polski dla duszpasterzy z dnia 22 października 1998 r. dotycząca małżeństwa konkordatowego, art. 3.

50 Tamże.

51 Por. J.M. Fernández Castaño, Natura e ruolo degli impedimenti matrimoniali, w: Gli impedimenti al matrimonio canonico. Scritti in memoria de Ermanno Graziani, Città del Vaticano 1989, s. 37-38 
osoba ludzka i samo małżeństwo ${ }^{52}$. Przepisy te zabezpieczają bowiem małżonków, ich związek oraz potomstwo przed potencjalnymi niebezpieczeństwami i trudnościami ${ }^{53}$. Prawodawca kościelny, świadom doniosłego znaczenia skutków cywilnych małżeństwa ${ }^{54}$, których istnienie dobrze służy tak samym małżonkom i ich dzieciom ${ }^{55}$, jak wielowymiarowej relacji łączącej męża i żonę ${ }^{56}$, wprost zakazuje asystowania przy zawarciu małżeństwa w sytuacji, która jawi się jako obiektywnie niekorzystna dla kontrahentów, ich ewentualnego potomstwa i przymierza małżeńskiego, które strony chcą ukonstytuować 57 .

Naturalnie, przyjęcie takiej zasady nie oznacza, iż ustawodawca nie dopuszcza - w poszczególnym i wyjątkowym przypadku - zawarcia małżeństwa kanonicznego bez skutków cywilnych. Wyrażenie zezwolenia na asystencję świadka kwalifikowanego w takiej sytuacji, dopuszcza on jednak tylko wtedy, kiedy kontrahenci - pouczeni o możliwych zagrożeniach i problemach - wskażą mu przynajmniej jedną ważną przyczynę natury pastoralnej, która uzasadnia uchylenie zakazu określonego w art. 3. Instrukcji Konferencji Episkopatu Polski

52 Por. H. Franceschi, Ius connubii y sistema matrimonial, w: El matrimonio y su expresión canónica ant el III Milenio X Congreso Internacional de Derecho Canónico, red. P.J. Viladrich, J. Escrivá-Ivars, J.I. Bañares, J. Miras, Pamplona 2001, s. 503504; tenże, Il diritto al matrimonio e la sua protezione nell'ordinamento canonico, w: „Iustitia et iudicium”. Studi di diritto matrimoniale e processuale canonico in onore di Antoni Stankiewicz, a cura di J. Kowal e J. Llobell, „Studi Giuridici” LXXXIX, Libreria Editrice Vaticana 2010, vol. I, s. 325.

53 Szerzej na ten temat zob. P. Majer, Zawarcie matżeństwa kanonicznego bez skutków cywilnych, Kraków 2009, s. 72-76.

${ }_{54}$ Zob. W. Góralski, Zawarcie matżeństwa konkordatowego w Polsce, s. 22.

55 Mowa tu m.in. o takich konsekwencjach natury cywilnej stosunku małżeństwa, jak: nazwisko małżonków i dzieci, domniemanie ojcostwa, obowiązek małżonków wspólnego zaspokajania potrzeb rodziny, obowiązek alimentacyjny, dziedziczenie ustawowe.

${ }^{56}$ Zawarcie małżeństwa ze skutkami cywilnymi niewątpliwie służy też samej relacji małżeńskiej, i to w wieloraki sposób. M.in. przyczynia się do zabezpieczenia trwałości związku męża i żony, utwierdza interpersonalną jedność małżonków, pozwala sprecyzować ich równe prawa, daje gwarancje dostępu do stosownych instrumentów prawnych, pomocnych w egzekwowaniu należnych uprawnień małżonków i ich potomstwa.

${ }^{57}$ Szerzej nt. racji, które wskazują na słuszność rozwiązania przyjętego w art. 3. Instrukcji Konferencji Episkopatu Polski dla duszpasterzy z dnia 22 października 1998 r. dotyczącej małżeństwa konkordatowego, zob. P. Majer, Zawarcie małżéstwa kanonicznego bez skutków cywilnych, Kraków 2009, s. 160-179. 
dla duszpasterzy z dnia 22 października 1998 r. dotyczącej małżeństwa konkordatowego.

Wspomniane rozwiązania, które przyjęła Konferencja Episkopatu Polski, w żadnej mierze nie stoją w sprzeczności, ani tym bardziej nie uchylaja zasady wolności kontrahentów w zakresie wyboru formy zawarcia małżeństwa, określonej w Konkordacie. Kwestie, które uregulowano w art. 3. Instrukcji Konferencji Episkopatu Polski dla duszpasterzy dotyczącej małżeństwa konkordatowego, nie stanowią też tych, o jakich układające się strony Konkordatu traktują w art. 27 wymienionej umowy, mianowicie problemów wymagających nowych i dodatkowych rozwiązań, które można uregulować w drodze umowy między Stolicą Apostolską i Rzeczpospolitą Polską albo uzgodnień pomiędzy Rządem Rzeczypospolitej Polskiej i Konferencją Episkopatu Polski upoważnioną do tego przez Stolicę Apostolską. Wspomniane dyspozycje natury prawnej, przewidujące stosowne zmiany w partykularnym prawie kanonicznym, jako precyzujące zasady prawne w przedmiocie zawarcia małżeństwa kanonicznego, nie wymagają uzgodnienia stron umowy konkordatowej. Sprawy te należą do wyłącznej kompetencji ustawodawcy kościelnego.

Jakkolwiek zmiana przepisów dokonana na mocy art. 3. Instrukcji Konferencji Episkopatu Polski dla duszpasterzy z dnia 22 października 1998 r. dotyczącej małżeństwa konkordatowego leży w interesie państwa polskiego, które jest zainteresowane zachowaniem porządku $\mathrm{w}$ zakresie relacji małżeńskich, nie wchodzi ona w zakres spraw forum mieszanego, których stanowienie wymaga stosownych umów albo uzgodnień sygnatariuszy Konkordatu.

\section{Zakończenie}

Rozwiązania legislacyjne, przyjęte w przedmiocie formy zawarcia małżeństwa - tak te uzgodnione w art. 10 Konkordatu między Stolicą Apostolską i Rzeczapospolitą Polską z 1993 r., określone w ustawach stanowiących realizację tego, co zapisano w art. 10 ust. 6 tej umowy, jak te zawarte w art. 3 Instrukcji Konferencji Episkopatu Polski dla duszpasterzy z dnia 22 października 1998 r. dotyczącej małżeństwa konkordatowego - niewątpliwie stanowią wyraz współczesnej kultury prawnej. Co więcej, tak normy określone przez ustawodawcę polskiego, jak te sprecyzowane przez prawodawcę kościelnego wskazują na zmianę postrzegania przez organy prawodawcze samej czynno- 
ści prawnej, jaką jest zawarcie małżeństwa. Ustawodawca kościelny, który nigdy nie kwestionował podległości małżeństw kanonicznych w sprawach czysto cywilnych władzy państwowej, zdecydowanie zabiega o to, aby - o ile to tylko możliwe - każde małżeństwo zawierane zgodnie z przepisami prawa kanonicznego cieszyło się pełnym uznaniem na forum cywilnym. Prawodawca polski z kolei, świadom zróżnicowania światopoglądowego i religijnego społeczności państwowej, nie uszczuplając w niczym swoich prerogatyw w zakresie określania przesłanek zawarcia małżeństwa, jego skutków i warunków rejestracji cywilnej, dopuszcza alternatywną formę zawarcia małżeństwa cywilnego, przed duchownym kościoła lub związku wyznaniowego cieszącego się stosownym uprawnieniem.

Przyjęte rozwiązania, to znaczy: uregulowania obu układających się stron, sygnatariuszy Konkordatu, dyspozycje ustawodawcy polskiego i prawodawcy partykularnego kościelnego w przedmiocie formy zawarcia małżeństwa posiadają wyraźnie ludzkie znamię. Wychodzą one naprzeciw oczekiwaniom znacznej części obywateli Rzeczypospolitej Polskiej, do niedawna pozbawionych możliwości zawarcia małżeństwa odpowiadającego ich przekonaniom religijnym, tak jednak, aby mogło ono uzyskać stosowny walor prawny także na forum cywilnym. Bez wątpienia regulacje te cechuje użyteczność, zasadność, społeczne ukierunkowanie, uszanowanie praw osoby ludzkiej; w przypadku zaś partykularnego ustawodawcy kościelnego - także troska o zagwarantowanie małżeństwom możliwie optymalnych warunków funkcjonowania i rozwoju, wprost zależnych od działań instytucji państwa.

\section{La liberté d'élection de la forme de contracter un mariage en Pologne Resumé}

L'auteur aborde une question de droit concernant la forme de contracter un mariage en Pologne sous un aspect historique en concentrant sa réflexion aux prescriptions légales en vigueur. 